DOI: https://doi.org/10.34883/PI.2021.9.4.009

UDC 616.314-084+616.31+613.955+616.314-083

Rozhko M., Haioshko O., Kosenko S., Prots' H., Han R.

Ivano-Frankivsk National Medical University, Ivano-Frankivsk, Ukraine

Рожко Н.М., Гайошко Е.Б., Косенко С.В., Проць Г.Б., Ган Р.З.

Ивано-Франковский национальный медицинский университет, Ивано-Франковск, Украина

\title{
Prevention of Oral Cavity Diseases in Senior School Children with Pectin-Containing Nonabrasive Products of Hygiene
}

\author{
Профилактика заболеваний полости рта у детей старшего \\ школьного возраста путем использования пектинсодержащих \\ безабразивных средств гигиены
}

\section{Abstract}

Introduction. Preparations based on pectin resources are also actively developed and studied in the world in the form of various pharmacopoeial forms, food additives and food products. In the pharmaceutical industry, they work as molding components. IFMNU has long conducted research on the development and clinical application of pectin-based agents for effective use in oral cavity.

Purpose. To determine the effectiveness of pectin-containing oral hygiene products in high school students aged $16-18$ years.

Materials and methods. On the base of IFNMU, 136 high school students who were in the basic group (BG) of the subjects were surveyed; 20 ones were the control group (CG). The age of the subjects was 16-18 years. Diagnostics was performed according to the international statistical classification of diseases and related problems. Treatment in both groups of BG and CG was identical, according to the standardization of treatment protocols.

Results. In the process of examination, treatment and prevention, it was found that under the action of hygienic and preventive means pectin-based, there was a process of normalization of the microflora of the oral cavity without violating its qualitative composition. The feasibility of using means pectin-based was confirmed by clinical efficacy. Namely, a significant reduction of soft plaque, normalization of hygienic indices, healing of postoperative wounds with reduced epithelialization and rapid disappearance of pain.

Conclusion. Thus, clinical and laboratory methods showed that the use of pectin-containing oral hygiene products in young people is more appropriate in terms of prevention of diseases of the oral cavity than the use of calcium-containing products. When removing teeth, we proved to use means pectin-based for bandages in schoolchildren aged 16-18 in order to reduce the postoperative period and prevent complications.

Keywords: tooth extraction, alveolitis, prevention, gingivitis, oral microflora.

\section{Резюме}

Введение. Препараты, основой которых являются пектиновые вещества, достаточно активно разрабатываются и изучаются в мире в виде разнообразных фармакопейных форм, пищевых добавок и пищевых продуктов. В фармацевтической промышленности их используют 
в качестве формообразующих компонентов. В ИФНМУ долгое время проводятся исследования по разработке и клиническому использованию средств на пектиновой основе для эффективного использования в полости рта.

Цель. Определение эффективности пектинсодержащих средств гигиены полости рта у школьников старших классов 16-18 лет.

Материалы и методы. На базе ИФНМУ было обследовано 136 школьников старших классов, которые входили в основную группу (ОГ) исследуемых. 20 составили контрольную группу (КГ). Диагностика проведена согласно Международной статистической классификации болезней и родственных проблем. Лечение в обеих группах, ОГ и КГ, было идентичным, согласно стандартизации протоколов лечения.

Результаты. В процессе обследования, лечения и профилактики обнаружено, что под действием гигиеническо-профилактических средств на пектиновой основе происходил процесс нормализации микрофлоры полости рта без нарушения ее качественного состава. Целесообразность применения средств на пектиновой основе была подтверждена клинической эффективностью. А именно значительным уменьшением мягкого налета, нормализацией гигиенических индексов, заживлением послеоперационных ран с сокращением сроком эпителизации и быстрым исчезновением болевого симптома.

Выводы. Клиническими и лабораторными методами доказано, что использование пектинсодержащих средств гигиены полости рта у молодежи более целесообразно в плане профилактики заболеваний полости рта, чем использование ими кальцийсодержащих средств. При удалении зубов у школьников 16-18 лет нами была доказана целесообразность использования средств на пектиновой основе для повязок с целью сокращения срока послеоперационного периода и профилактики осложнений.

Ключевые слова: удаление зубов, альвеолит, профилактика, гингивит, микрофлора полости рта.

\section{- INTRODUCTION}

The pectin-containing oral care means are widely developed and studied in Ukraine shaped like various pharmacopeial forms, supplements, and foodstuffs. Borshchahivskyi chemical pharmaceutical plant produce "quercetin" shaped in grains. Boehringer ingelheim pharma produces means pectin-based. In the institute of experimental radiology SCRM it was developed and studied powdered and water dissolved oral care means pectin-based. Kyiv pharmaceutical factory produces pectin-based supplement. Kyiv scientific-research institute produces jelly foodstuff with pectin and phytosorbent. Pectins and pectin-based products are produced all over the world (Mohnen D., Doong R.L., Liljebjelkek L. et al. 1996). In pharmaceutical industry they are used as shaped-like components and for capsules (it has been adopted by Ukrainian Ministry of Health № 336 as of 19.06.2007 "The adoption of the names of supplements and colouring agents contained in medications").

Ivano-Frankivsk National Medical University has been supervising the study of the development of clinical application of pectin-based oral care means for effective treatment of oral cavity for a long time [1]. Means pectin-based was initially used for the caries treatment and its prevention endogenously and exogenously in the most vulnerable groups of people like: pregnant women, nursing mothers and children under 3. Tooth 
powder-gel for brushing teeth was introduced and tested. Provided study research was introduced in the PhD thesis ("Antenatal and postnatal caries prevention with pectin-containing substances in pregnant women, nursing mothers and children". Havryliv H.M., 2003). Pectin-based bandages application was grounded due to the analysis of information and patent sources. In 2006-2007 it was developed and clinically tested the non-setting dental bandage for treatment and prevention of pathologic processes in the oral cavity. Pectin-based as an apple pharmacopeial pectin was used for the bandages endogenously. Provided study research was introduced in the PhD thesis ("Alveolitis prophylaxis". Haioshko O.B., 2019).

Oral cavity hygiene preserves its health. The most important is to prevent dental deposit onset. Dental deposit is the microflora accumulation on the teeth surface. It originates as a result of microorganisms absorption on the surface of the tooth enamel. Such an absorption works out due to specific glue-like indissoluble in water polysaccharides, dextrines as well as specific albumins of saliva. Further reproduction and synthesis of extracellular substances affect the dental deposit [2]. Bacterial albumins are allergens and toxins. Penetrating into the gum tissue they cause its insult (inflammation and dystrophy). In the next process of dental deposit evolution aerobiosis is changed into anaerobiosis along with $\mathrm{pH}$. Calcium and phosphorus are accumulated. Dental calculus is generated depositing on the teeth especially next to the dentogingival edge. It prevents from gum liquid circulating [3]. Microorganisms in the oral cavity affect the dental calculus generation. $1 \mathrm{mg}$ of dental calculus contains $800 \mathrm{mln}$ of microorganisms. Their composition is different. Among preventive measures the most important are those for hygiene of oral cavity [4]. Hygienic measures prevent from dental calculus formation more or less. The top priority importance is the early removal of the dental calculus deposition with toothbrush assisted with hygienic preventive means. Young people are lack of understanding and motivation to care for their oral cavity. Therefore it is highly recommended for the educator to professionally not only explain the importance of the preventive actions but also to orient them at keeping them on to preserve their health including ergonomics, social adaptation, with corresponding care for the oral cavity [5].

The major hypothesis of our study was: appropriateness to use and get lasting clinical preventive effect when applying the pectin-containing nonabrasive hygienic means pectin-based considering its properties in contrast with the conventional calcium-containing hygienic ones.

\section{- PURPOSE OF THE STUDY}

To set the efficiency of pectin-containing hygienic means of oral cavity in $16-18$ senior school children.

\section{Tasks to achieve the purpose:}

1. To set the actual stomatological problems in senior school children.

2. To assess the efficiency of the suggested pectin-containing hygienic preventive means pectin-based aiming at averting oral cavity from diseases.

3. To give ground proving its efficiency with clinical research methods. 


\section{- MATERIALS AND METHODS}

At IFNMU 36 senior school children from the treatment group (TG) were examined. In the control group (CG) there were 20 of them. The age group of all examined is 16-18. Diagnostics was held due to international statistical classification of diseases and related problems. The treatment in both groups was identical due to standardized treatment protocol. The TG tested pectin-based as an oral cavity hygienic-preventive means. The CG used means of hygiene from commercial network without identification. In the TG the bandage with means pectin-based t was used for those who had tooth extraction during the elective surgery to restrict the microbial flora aggression of the oral cavity. The treatment for this group was previously developed [4]. In the CG the treatment was held due to the standard protocols for surgical stomatological patients. The examination was held due to the universally adopted procedure: inquiry, examination, testing. The oral cavity microbial flora of all tested patients was identified in the laboratory. Stomatological diagnosis was based on clinical examination, clinical-instrumental examinations, clinical hygienic indices, wound healing rate, $\mathrm{X}$-ray examinations.

\section{- RESULTS AND DISCUSSION}

The examination results were recorded on the same day (the first day), on the 7-8 days, and on the 14-16 days. It was determined by the results of the first day that $87 \%$ of young people had disturbed occlusion. The disturbed occlusion was insignificant with turning separate teeth endwise, overlapping one another in the dentition, with vestibular or oral inclination. $26 \%$ of patients had scissors bite. $97.5 \%$ of patients had caries and $22.6 \%$ had its complication. $15.1 \%$ of patients had to get teeth extracted. $87.8 \%$ had periodontal tissues disease as a catarrhal gingivitis. $6.6 \%$ of patients had viral aphthous stomatitis and $3.4 \%$ of patients had infectious-allergic aphthous stomatitis. During the first day of examination the hygienic indices were recorded that proved the good quality of caring for the oral cavity. It should be noted the care quality of oral cavity was poor both in the CG and in the TG. Due to OHI-S Oral Hygiene Indices with 1.3-3.0 it corresponds to fair oral cavity hygiene in $66.5 \%$; with $3.6-6.0$ corresponds to poor oral cavity hygiene in $10.9 \%$. Index assessment criteria Green - Vermillion: dental deposit - Debris-index (DI): corresponds to 3 in 90.0\% of cases; Calculusindex $(\mathrm{Cl})$ corresponds to 1 in $25.5 \%$ of cases. It proves the poor quality of hygiene, existence of soft and hard dental deposit in both groups, and the lack of preventive stomatological measures.

In the process of examination, treatment, and prophylaxis it was elicited that when pectin-based was applied as a hygienic-preventive means, the oral cavity microflora was normalized without changing its qualitative composition (Table). The clinical efficiency of with means pectin-based and its application has been proved: a significant dental deposit removal, hygienic indices normalization, post-extracting wounds healing with the reducing period of epithelization and rapid decurrence of algesic symptom.

Clinical tests, held by us, confirm the laboratory research given in Table. The data given in the table prove that the CG being on treatment had acidophilic lactobacteria reduced rapidly after 7-8 days of treatment but after 16-18 days had them appeared again. An abundant number of 
Dynamics of qualitative indices of oral cavity microflora analysis in 16-18-year-old school children of control and treatment groups with use of hygienic-preventive products on pectin basis

\begin{tabular}{|c|c|c|c|c|c|}
\hline \multicolumn{6}{|c|}{ Analysis of oral cavity microflora $(M \pm m) p^{*}<0.05$} \\
\hline 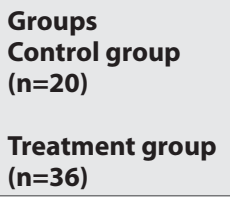 & $\begin{array}{l}\text { Examina- } \\
\text { tion area }\end{array}$ & Microflora & $\begin{array}{l}1^{\text {st }} \text { day } \\
\text { Quality in the } \\
\text { vision field } \\
\text { (VF) }\end{array}$ & $\begin{array}{l}7-8^{\text {th }} \text { days } \\
\text { Quality in the } \\
\text { vision field } \\
\text { (VF) }\end{array}$ & $\begin{array}{l}14-16^{\text {th }} \text { days } \\
\text { Quality in the } \\
\text { vision field } \\
\text { (VF) }\end{array}$ \\
\hline Control group & \multirow{4}{*}{ Gum } & \multirow{2}{*}{$\operatorname{Cocci}^{* *}$} & $\begin{array}{l}\text { Severe in the } \\
\text { vision field }\end{array}$ & $\begin{array}{l}\text { Moderate in the } \\
\text { vision field }\end{array}$ & $\begin{array}{l}\text { Moderate in the } \\
\text { vision field }\end{array}$ \\
\hline Treatment group & & & $\begin{array}{l}\text { Severe in the } \\
\text { vision field }\end{array}$ & $\begin{array}{l}\text { Moderate in the } \\
\text { vision field }\end{array}$ & $\begin{array}{l}\text { Moderate in the } \\
\text { vision field }\end{array}$ \\
\hline Control group & & \multirow{2}{*}{$\begin{array}{l}\text { Acidophilic } \\
\text { lactobacteria }\end{array}$} & $27.1 \pm 5.7$ & $5.4 \pm 1.7$ & $46.5 \pm 2.4$ \\
\hline Treatment group & & & $27.5 \pm 4.7$ & $3.1 \pm 2.7$ & $17.1 \pm 5.7$ \\
\hline Control group & & Fungi & $\begin{array}{l}\text { Severe in the } \\
\text { vision field }\end{array}$ & $2.5 \pm 0.9$ & $26.5 \pm 4.4$ \\
\hline Treatment group & & Candida & $\begin{array}{l}\text { Severe in the } \\
\text { vision field }\end{array}$ & $22.5 \pm 6.9$ & $12.1 \pm 5.7$ \\
\hline \multirow{2}{*}{$\begin{array}{l}\text { Control group } \\
\text { Treatment group }\end{array}$} & & \multirow{2}{*}{$\begin{array}{l}\text { Mycelium of the } \\
\text { yeast fungus }\end{array}$} & $\begin{array}{l}\text { Severe in the } \\
\text { vision field }\end{array}$ & $4.5 \pm 0.9$ & $22.2 \pm 4.6$ \\
\hline & & & $\begin{array}{l}\text { Severe in the } \\
\text { vision field }\end{array}$ & $17.5 \pm 4.8$ & $8.1 \pm 5.3$ \\
\hline Control group & & \multirow{2}{*}{$\begin{array}{l}\text { Fusobacterium } \\
\text { Vincent }\end{array}$} & $\begin{array}{l}1 / 4 \text { of severe in } \\
\text { the vision field }\end{array}$ & $4.5 \pm 0.9$ & $1.5 \pm 1.1$ \\
\hline Treatment group & & & $\begin{array}{l}1 / 4 \text { of severe in } \\
\text { the vision field }\end{array}$ & $0.5 \pm 0.2$ & $0.5 \pm 0.2$ \\
\hline Control group & & Spirochetes & $\begin{array}{l}1 / 4 \text { of severe in } \\
\text { the vision field }\end{array}$ & $4.5 \pm 0.2$ & $2.5 \pm 0.1$ \\
\hline Treatment group & & Vincent & $\begin{array}{l}1 / 4 \text { of severe in } \\
\text { the vision field }\end{array}$ & $2.8 \pm 0.6$ & $0.5 \pm 0.2$ \\
\hline \multirow{2}{*}{$\begin{array}{l}\text { Control group } \\
\text { Treatment group }\end{array}$} & & \multirow{2}{*}{ Mouth amoeba } & $0.5 \pm 0.1$ & - & - \\
\hline & & & $0.5 \pm 0.2$ & $0.5 \pm 0.2$ & $0.5 \pm 0.2$ \\
\hline \multirow{2}{*}{$\begin{array}{l}\text { Control group } \\
\text { Treatment group }\end{array}$} & & \multirow{2}{*}{$\begin{array}{l}\text { Mouth } \\
\text { trichomonad }\end{array}$} & $8.5 \pm 3.1$ & - & - \\
\hline & & & $8.5 \pm 2.2$ & $4.5 \pm 0.2$ & $0.5 \pm 0.2$ \\
\hline \multirow{2}{*}{$\begin{array}{l}\text { Control group } \\
\text { Treatment group }\end{array}$} & \multirow{2}{*}{ Cheek } & \multirow{2}{*}{ Candida Fungi } & $\begin{array}{l}\text { Severe in the } \\
\text { vision field }\end{array}$ & - & - \\
\hline & & & $\begin{array}{l}\text { Severe in the } \\
\text { vision field }\end{array}$ & $16.5 \pm 3.4$ & $10.2 \pm 3.7$ \\
\hline \multirow{2}{*}{$\begin{array}{l}\text { Control group } \\
\text { Treatment group }\end{array}$} & \multirow{2}{*}{ Tongue } & \multirow{2}{*}{ Candida Fungi } & $\begin{array}{l}\text { Severe in the } \\
\text { vision field }\end{array}$ & - & $35.5 \pm 4.7$ \\
\hline & & & $\begin{array}{l}\text { Severe in the } \\
\text { vision field }\end{array}$ & $22.5 \pm 6.9$ & $7.1 \pm 0.7$ \\
\hline
\end{tabular}

Notes: ${ }^{*} \mathrm{p}$ - authenticity of indices difference comparing to the values after 7-8 days of treatment; ${ }^{* *}$ no focus on cocci microflora identification in this research.

acidophilic lactobacteria proves the availability of caries in the CG. In the TG this index was significantly reduced after the initial study although the reducing tendency was observed after 7-8 days of treatment. Mycelium of the yeast fungi and Candida fungi are the indicators of sugar both in blood and saliva. Their presence proves the availability of acid medium in the oral cavity affecting the gum inflammation in the CG being under study. Whereas 
in the TG their presence was gradually reduced proving the oral cavity alkalescence and gum inflammation retardation. Vincent Fusobacteria and Spirochetes can exist only with oxygen scarcity, a great amount of dental deposit, and adherent dendrite. Their presence proves oxygen scarcity in the oral cavity of the patients under study from the CG. Mouth amoeba is a saprophytic flora. In small numbers it stabilizes the symbiosis of normal microbial flora. Total their antisepsis disturbs the oral cavity geobiocoenosis. The laboratory research proves it with patients data from the CG.

The attained results in the treatment of the TG were fixed after rehabilitation period when school children were prescribed with the dietary treatment with pectin substances and cellular tissue contained in the foodstuffs. Microbial flora balance was normalized after two weeks of treatment in the TG. Whereas in the CG it was necessary to add either the professional hygiene of the oral cavity or treatment. Surgical procedures of teeth extraction were held in both groups electively during the rehabilitation period as there were no emergencies. After teeth extraction in the patients from the CG a number of Candida fungi doubled. It can be explained as the oral cavity homeostasis. Three school children had the activation of anaerobic flora in their analysis. Besides the teenagers' mental lability it can be explained as the scarce hygiene of the oral cavity and anaerobic flora activation added to the pathological process. Open wound was infected, algesthesia prevented from autopurification after tooth extraction. The period of the wound healing was extended. Discomfort and algesthesia staved off the schoolchild from studying and having ordinary way of life. In the TG after tooth extraction the wound had surface tension healing in two days. The application of hygienic-preventive means Pectodent and pectin bandage for protecting and treating the wound surface after tooth extraction warded off the microbial flora to be virulent. Oxygen penetrated through the bandage. It prevented from the growth of anaerobic fusospirill. After the treatment procedures and raise of awareness among the future students delivered by the dentist and lecturer, the oral cavity hygiene advancement was observed in both groups. For validation and differentiation of the results index Silness Loe was added. It includes the thickness of the dental deposit in the cervical area of the tooth. In the TG of patients when the school children applied hygienic-preventive means pectin-based, $32 \%$ of them had dental deposit index $-0 ; 60 \%$ of them had dental deposit index $-1.8 \%$ of them had plaques from the thin to the moderate layers with the index -2 . In the CG of patients who applied preventive means of hygiene containing calcium it was observed the severe dental deposit in the area of gum sulcus and interdental spatium in most of them up to $72 \%$ with the index $-3.18 \%$ of patients had thin layer of dental deposit with the index $2.10 \%$ of teenagers from this group were with the index -0 . Therefore the application of pectin-containing means of hygiene by the senior school children is more recommended as the prophylaxis of oral cavity diseases than those with calcium-containing ones.

\section{- CONCLUSIONS}

1. When examining the school children of 16-18 the study provided data to the next stomatological information: $97.5 \%$ had caries and $22.6 \%$ had its complication. $15.1 \%$ had an absolute necessity for the teeth extraction. 
$87.8 \%$ had the inflammation of the periodontal tissues disease as a catarrhal gingivitis. $6.6 \%$ of patients had viral aphthous stomatitis and $3.4 \%$ of patients had infectious-allergic aphthous stomatitis. $87 \%$ of young people under study could have a disturbed occlusion.

2. Clinical and laboratory methods proved that the application of pectin-containing hygiene means of oral cavity by the youth is more recommended as a prophylaxis of oral cavity diseases than calciumcontaining ones.

3. Means pectin-based is worth applying for the bandages after tooth extracting in the school children of 16-18 to reduce the after-surgery period and prevent from complications.

4. The model role of the teacher is very important in the organized communities when teaching the youth. He is not only the professional educator, but also a creative personality setting the goal, except for professional knowledge, to deliver the new system of knowledge relating to the youth self-help preserving the maxillofacial system as a component of biological and social systems.

Authors' contribution: conceptual and study design, editing - Rozhko M.; conceptual and study design, statistical data processing, writing Haioshko O.; conceptual and study design, material compilation and analysisKosenko S.; material compilation and processing - Prots' H.; literature review, editing - Han R.

Conflict of interest. The authors declare no conflict of interest.

\section{REFERENCES}

1. Hlushko L. (ed.) (2013) General practice - family medicine. Practical guide. Ivano-Frankivsk, 656 p. (in Ukrainian)

2. Ogareva A. (2007) Clinical-instrumental assessment of periodont in musicians playing the wind instruments. Author's abstract. M., 24 p. (in Russian)

3. Order of the Cabinet of Ministers as of 08.11.2000 № 1662 "The adopted list of professional diseases". O.1. To adopt the list of professional diseases. (in Ukrainian)

4. Haioshko O. (2015) Innovative technologies for wounds healing after teeth extraction. Modern features of development of biological science as factors of solution of pressing problems of human survival and the natural environment. London, pp. 55-57. (in Ukrainian)

5. Kosenko S., Haioshko O., Kononenko Yu. (2015) Pectodent. Application technology, part II. Denta Club, 2 (45), pp. 42-45.

Submitted/Подана: 13.10 .2021

Accepted/Принята: 22.11.2021

Contacts/Контакты: gan181168@gmail.com

The article is published in the author's edition. 